\section{THE SOUTHPORT MEETING OF THE BRITISH ASSOCIATION.}

SINCE the publication of the first article on the approaching meeting of the British Association (July 9, p. 224), the following additional arrangements have been made :-

Sir George Pilkington will give a garden party to Ios members at his residence, Belle Vue, Southport on Monday, September I4. Mr. William. Vernon will give a garden party to Ioo members at Wyborne Gate, Birkdale, on T'uesday, September 15.

An exhibition of metcorological and magnetic instruments, diagrams, books, \&c., will be held in the laboratory and lower corridor of the Science and Art Schools, immediately adjoining the reception room. The exhibition, owing to the presence of the International Meteorological Committee in Southport, is likely to be of unusual interest. Exhibits are promised by the Royal Observatory, Greenwich; the Solar Physics Observatory; the Metcorological Office; Kew Observatory; the Scottish Meteorological Society; the Royal Meteorological Society; Captain Wilson-Barker; the Scientific Instrument Co., Cambridge; Mr. W. H. Dines; Prof. Pernter; Dr. A. L. Rotch; Captain Creak; Dr. Mill; the Radcliffe Observatory, Oxford; Mr. C. T. R. Wilson; Mr. J. Aitken; Mr. Joseph Baxendell; and Mr. Halliwell.

A loan muscum of objects of local scientific and archæological interest is being organised.

The printing of the "Handbook" is now complete. The contents are as follows:-(1) "Southport: Historical and Descriptive"; (2) "Southport as a Health Resort," by Dr. J. J. VVeaver and Dr. A. V. Wheeler; (3) "The Meteorology of the Southport District," by Joseph Baxendell ; (4) "The Geology of the Southport District," by Harold Brodrick and Edmund Dickson-- (a) "The Ribble Estuary," by Edmund Dickson; (5) "The Botany of the District," by W. H. Stansfield and Henry Ball-- $(a)$ " A note on Hypopity's Monotropa," by Henry Ball, (b) "The Mosses of the District," by J. A. Wheldon, (c) "The Hepaticæ of the District," by J. A. Wheldon; (6) Zoology-(a) "Protozoa-Foraminifera," by Dr. G. IV. Chaster, (b) "Lepidoptera," by F. N. Pierce and J. R. Charnicy, (c) "Coleoptera," by Dr. G. W. Chaster and E. J. Burgess Sopp, (d) "Araneæ," by Dr. A. R. Jackson, (e) "Mollusca," by Dr. G. W. Chaster, $(f)$ "Marine Fauna and Fisheries," by Prof. W. A. Herdman, F.R.S., and Isaac C. Thompson, $(g)$ "A Note on the Vertebrate Fauna of the District"; $(\xi)$ "Martin Mere and its Antiquities," by Harold Brodrick ; (8) "Archæology," by Willis Brunt; (9) "Sketch of the Life and Works of the Rev. Jeremiah Horrocks," by G. Napier Clark.

The Cambridge Scientific Instrument Company will fix a Callendar temperature recorder in the reception room, the instrument being connected electrically with a thermometer suitably cxposed to the air outside the building.

The committee of the British Association appointed at Belfast for the investigation of the upper atmosphere by means of kites will, if possible, show the working of the kite apparatus during the meeting of the Association at Southport, in illustration of the experiments carried out by Mr. W. H. Dines, under the auspices of the Royal Meteorological Society and of the British Association, with the aid of grants of money from the Association and from the Government Grant Committee of the Royal Society. The committee hoped to have the advantage of the services of an Admiralty vessel for a sufficient period to include the meeting at Southport, for, in compliance with the request of the Royal Society, the No. 1763 , voL. 68 ]
Lords Commissioners were good enough to assign a vessel for the experiments, but unfortunately she met with an accident at Devonport and sank in the harbour. She is consequently not available. The local committee of the British Association is trying to assist the committee to obtain a steamer for the purpose of carrying out the experiments at Southport.

The title of Dr. J. S. Flett's lecture to working men on Saturday, September 12, is "Martinique and St. Vincent: the Eruptions of I902," with lantern illustrations.

The railway companies, as before stated, will issue tickets to Southport available from September 8 to 18 inclusive, but in the case of the Irish railways the tickets will be available from September 7 to 19 inclusive. The committees of the principal clubs have agreed to extend the privilege of honorary membership to non-resident members of the Association during the week of the meeting.

The Saturday afternoon excursion to Hoole and Rufford will take the form of a motor-car run. More than twenty cars have been placed at the disposal of the committee by their owners, and it is hoped that this excursion will be a popular one. Tea will be served at Rufford Old Hall. The excursion to the Wirral Peninsula is specially intended for geologists and botanists, and geological and botanical parties will be formed in connection with the Windermere excursion.

A specially prepared plan of the town in colours will be inserted in the local programme, and a plan of the Municipal Buildings, where most of the meetings of the Association will be held, will also be included.

A list of those members who had intimated their intention of being present at the meeting up to July I4 has been printed, and can be obtained at the local office. The following names of foreign and American corresponding members, and members of the International Meteorological Committee, are included in the list:--Prof. G. S. Atkinson, Cornell University, U.S.A. ; Dr. Von. Bebber, Hamburg ; Dr. R. Billwiller, Zurich; Prof. Ludwig Boltzmann, Vienna; $M$. Trisserenc de Bort, Paris; Captain Chaves, St. Miguel, Azores; Mr. W. Davis, Cordoba, Argentine; Pref. G. Gilron, Louvain; M. A. Gobert, Brussels; the Comte A. de Gramont, Paris; Prof. Hellman, Berlin; Prof. H. Hergesell, Strassburg; Prof. H. H. Hildebrandsson, Upsala; Prof. Lignier, Caen; Prof. C. Lombroso, Turin; Dr. T. P. Lotzy, Leyden; Mr. G. G. MacCurdy, Newhaven, Conn., U.S.A.; Prof. E. Mascart, Paris; Prof. H. Mohn, Christiania; Prof. Willis Moore, Washington, U.S.A.; Prof. Simon Newcomb, Washington, U.S.A.; Prof. L. Palazzo, Rome; Prof. Paulsen, Copenhagen; Prof. J. M. Pernter, Vienna; Dr. A. L. Rotch, Blue Hill Observatory, Mass., U.S.A.; General Rykatcheff, St. Petersburg; Prof. M. Snellen, Utrecht; Prof. R. H. Thurston, Cornell University, U.S.A.; Dr. H. C. White, University of Georgia, U.S.A.; Prof. E. Zacharias, Hamburg.

The Mayor of Southport (Mr. T. T. L. Scarisbrick) has issued more than a hundred invitations to members of the Association and to distinguished foreigners who will be present in Southport to a dinner at his residence, Greaves Hall, Banks, on Wednesday, September I6, to mect Sir Norman Lockyer, president of the British Association, and Prof. E. Mascart, president of the International Meteorological Committee.

The Southport Literary and Philosophical Society, which was responsible for the preliminary negotiations which resulted in the holding of this year's meeting of the Association at Southport, has arranged to hold the opening meeting of its winter session on Thursday, September 17 . On this occasion Prof. A. R. 
Forsyth, F.R.S., has consented to deliver an address on "Universities: their Aims, Duties, and Ideals." Invitations have been issued to many members of the British Association, as well as to others interested in educational work.

\section{THE CENTENARY OF HEIDELBERG UNIIERSITY.}

$\mathrm{O}^{2}$ $\mathrm{N}$ August $5^{-8}$ the Lniversity of Heidelberg celebrated the centenary of its re-establishment. The university, one of the oldest universities of the modern world, was originally founded in 1386 by the Palsgrave Ruprecht I. of the Palatinate. At that time Heidelberer was the seat of the princely residence and capital of this wealthy State of the middle agres, and the young university did good work from the point of view of those times. The "German Medici," Otto Heinrich $(1,56)$, delivered the university from the chains of scholastic pedantry and inspired in her the ideas of the Renaissance and of the Reformation. The thirty years' war had a disastrous effect on this town and its university, as, indeed, it had on all Germany; nevertheless, the Elector, Karl Ludwig ( $\left.165^{\circ}\right)$, again gave it a short period of prosperity. But with the year 1685 commenced for the Palatinate and the university a long period of sorrow and loss.

Soon the positions held by broad-minded inquirers and teachers were occupied by imperfectly educated members of Catholic Orders, and the university sank to a mere confessional school. Scientific research degenerated in to the school-divinity of the middle ages, appointments were given by those in control to their relatives, and very strict tests in matters of faith were imposed.

The result was that, during the eighteenth century, scarcely any work of scientific value was done by the university, and the number of students sank to a minimum. The condition of affairs was made still worse by the loss of the income hitherto derived from the possessions on the other side of the Rhine, which were then in the hands of the French.

Though the Bavarian Prince, into whose hands Heidelberg had fallen in 1799 , commenced to break the dominion of the monks, and though he sought to procure new incomes for the impoverished university, her renovation was really the work of the Badish Prince, Carl Friedrich.

By the division of Germany in 1803 , Heidelberg came into the possession of the Elector, Carl Friedrich, who later became the Grand Duke of Baden. Without delay, he commenced to re-establish the Heidelberg University, to give to her a broad constitution resting on high ideals, and last, but not least, to procure the necessary money.

He endowed the university with an annual sum of 50,000 florins, which had to be raised by the State. He reserved to himself the office of "Rector" of the university, a charge which since that time has rested in the hands of the Grand Dukes. The essential principle of the reorganisation is to be found in the rule that "the professors' chairs shall be filled by the most worthy competitors, without any consideration of their religion."

The names of the first professors of that time are still well known. I only recall the names of the theologians Daub, De Wette, Paulus, the jurists Thibault and Zachariae, the physician Naegele, and the philosophers T. H. Voss, Creuzer, and Bökh. It is the centenary of this reorganisation that the university has just now celebrated.

Indeed, what these beginnings promised, the nineteenth century has seen fulfilled, and the university has taken her place among the foremost of the world. Excellent scientific laboratories, observatories, and hospitals have been built, a monumental library-building is in the process of construction, and the first modest annual endowment of 50,000 florins has grown to one of 800,000 marks, to which has been added a regular special grant, amounting in the budget of I902-03 to almost exactly a million of marks, so that at the present time about $6_{5}, 000$ pounds sterling are expended annually upon the university.

If one remembers that Baden has about two millions of inhabitants, and that it posscsses not only one, but three universities (Heidelberg, Freiburg, and the Karlsruhe Polytechnicum), it must be confessed that a great work has been accomplished. The number of professors and doconls of the Heidelberg Lniversity is now $\mathrm{I}_{5} \mathrm{I}$, that of students 1884 .

The work of the university during the nineteenth century has recrived the acknowledgment of educated men all over the world. The development of the history of Christianity is connected with the Heidelberg names, Hitrix, Llmann, Rothe, Schenkel, and Holsten; lawyers and political cconomists appreciate full the infuence of Vangerow, Windscheid, Bluntschili, Mittermaier, Renaud, and Knies; physicians will remember the names of Chclius, Pfeuffer, Arnold, and Gegenbaur. The names of the philosophers Hegel and Zeller are known far and wide. Well known, too, are the philologists Koechly, Ribbeck, Wachsmuth, Zaugeneister, and Bartsch, and the historians Schlosser, Häusser, Gervinus, and Treitschke. The mathematicians Hesse and Fuchs, and the leaders in natural science, Hofmeister, Kekulé, Kopp, and above all Bunsen, Kirchhoff and Helmholtz, have spread the glory of Heidelbers over the world.

The greatest credit for the success of the Heidelberg University in the past century must be attributed to the Grand Duke Friedrich, now seventy-six years old, who-during the fifty-one years in which he has been Rector-has made the university what she is to-day.

In the evening of August 5 the students formed a torch-light procession in honour of the Grand Duke. The next morning, after a festival divine service, the Actus was held in the Aula of the university, where the Grand Duke, the Minister, the deputations of other universities and corporations, and the acting Prorector of the university (Prof. Czerny) delivered addresses. After a banquet a reception was given by the city in the poetical ruins of the celcbrated Heidelberg Castle.

On August 7 the historian of the university (Prof. Marks) gave a historical address, concerning the development of the scientific life of the university during the past century. In the evening the students held their great "Commers."

The announcement of the honoris causa doctores took place next morning. In the branch of medicine the following men of science were elected :-M. T. H. Dunant, Geneva; Prof. Sv. Arrhenius, Stockholm; Sir IV. Ramsay, London; Prof. P. Lenard, Kiel; G. Schweinfurth, Riga; G. Moynier, Geneva.

In the branch of natural science the following were elected :- Mathematics, M. G. Darboux, Paris; physics, Dr. R. T. Glazebrook, London; astrophysics, Sir William Huggins, London; chemistry, Prof. S. Cannizzaro, Rome; mineralogy, Prof. F. Fouqué, Paris; astronomy, Prof. E. C. Pickering, Cambridge, U.S.A.; zoology, Prof. E. Maupas, Algiers; botany, A. Cogniaux, Nivelles.

In the evening of August 8 a reception was given by the Grand Duke and the Grand Duchess at their castle in Schwetzingen. Sunday, August 9, was devoted to excursions in the neighbourhood, and at night an illumination of the castle, and a great display of fireworks on the Neckar, brought the festivities to a close.

The present generation has expressed by these splendid meetings that it appreciates highly the benefit 